\author{
G.S. Sultanbayeva ${ }^{1}$ (D) R. Kertayev ${ }^{2}$ iD , O.P. Lozhnikova ${ }^{\text {iD }}$, A. Ashimova ${ }^{1}$ \\ ${ }^{1}$ Al-Farabi Kazakh National University, Kazakhstan, Almaty, \\ e-mail: Gulmira.Sultanbayeva@kaznu.kz, \\ e-mail: Olga.Lozhnykova@kaznu.kz, \\ e-mail: aika910526@hotmail.com \\ ${ }^{2}$ Gumilyov Eurasian National University, Kazakhstan, Nur-Sultan, \\ e-mail: rinakhabar@mail.ru
}

\title{
DIGITAL MEDIA PREFERENCES: IN THE FOCUS OF SOCIAL RESEARCH
}

This research presents the results of a sociological study on the media behaviour of the adult population of Kazakhstan viewers of TV «Khabar» in the context of the issue of worldview orientations in the digital age. The aim of the research is to determine the specifics of media consumption of digital technologies of the population of Kazakhstan, as well as to identify media preferences of the adult population.

The main tasks of our empirical research are firstly to determine the mechanism of access to the main technical means of communication and digital information channels, and secondly to determine the media behaviour of active users of digital sources.

The research methodology is based on quantitative and qualitative methods. The results of the study show a segmentation of the Kazakh audience in terms of usage of digital channels, in terms of information consumption and in terms of media preferences. All regions of the country can be divided into two groups according to the dominant type of television connection into areas where rural population prevails and into areas with a higher level of urbanization. The analysis shows that digital television is being introduced in all areas, with mobile Internet having begun to compete with wired Internet.

The identification of media behavior of the adult population of Kazakhstan by television viewers of the Khabar channel in the focus of development and modernization of the digital era determines the practical and scientific significance of this empirical study.

The research methodology is based on quantitative and qualitative methods: interviewing the middle of the target group and working in focus groups.

The results of the study show that the segmentation of the Kazakhstani audience of digital information channels by style of consumption and the characteristics of the media preferences of the audience of the Khabar TV channel differ.

The results of the study can be used in applied work in on social journalism.

Key words: TV «Khabar», digital media, digital transformation, media activity, media behaviour, media consumption.

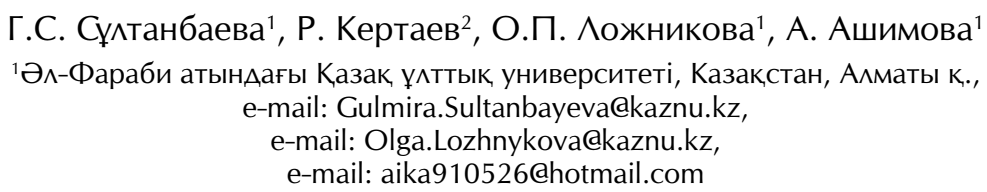

${ }^{2} \wedge$. Гумилев атындағы Еуразия ұлттық университеті, Қазақстан, Нұр-Сұлтан қ., e-mail: rinakhabar@mail.ru

\section{Цифрлық медиаталғам: әлеуметтік зерттеулер фокусында}

Мақалада цифрлық дәуірдегі дүниетанымдық көзқарастар контексінде Қазақстан тұрғынАарының, атап айтқанда «Хабар» арнасы көрермендерінің медиатұтыну ерекшеліктерін айқынАауға арналған зерттеу нәтижелері қарастырылды.

Зерттеу мақсаты - Қазақстан тұрғындарының цифрлық технологияларды қолдану ерекшеліктері мен медиаталғамын, сондай-ақ, медиа тұтынушының заманауи қажеттіліктерін анықтауға бағытталды.

Эмпирикалық зерттеулердің негізгі міндеттеріне коммуникацияның басты техникалық құралдарына қолжетімді механизмдері мен ақпараттың цифрлық арналарын және цифрлық деректерді белсенді қолданушылардың медиаталғамын айқындау жатады.

Цифрлық дәуірдің дамуы мен модернизациясы фокусында Қазақстанның ересек тұрғынАарының, соның ішінде «Хабар» арнасы телекөрермендерінің медиаталғамын айқындау аталмыш эмпирикалық, зерттеулердің практикалық және ғылыми маңызын айқындайды. 
Бұқаралық ақпарат құралдарының аудиторияға ықпалын зерттеуде негізгі коммуникация техникалық құралдарына қолжетімдіктен бастап, түрлі ақпарат көздеріне сенімділік деңгейі, ақпараттық тақырыптарды таңдау сарындары, түрлі дереккөздерін белсенді қолдану амалдарын қарастыру, әлеуметтік желілерді таңдау мен белсенділігі зерттеу жұмысының басты міндеттері саналды. Әлеуметтік зерттеудің «Хабар» агенттігінің қоғамдық даму стратегиясын анықтаудағы орнын айқындау жұмыстың ғылыми және қолданбалы маңызы саналады.

Зерттеу жұмысында қолданбалы әлеуметтік зерттеу әдістері қолданылды. Жұмыстың методологиялық негіздеріне сандық және сапалық зерттеулер, атап айтқанда, тұрғындар арасындағы бұқаралық сауалнама, фокус-топтық талдаулар жатады. Сауалнамададемографиялық, гендерлік, жас, этникалық, және әкімшілік ерекшеліктеріне қатысты анкеталық, фокус-топтық, зерттеулер жүргізілді.

Зерттеу жұмысының нәтижелері көрсеткендей, қазақстандық аудиторияның цифрлық арналарды қолдану ақпаратты пайдалану және медиа талғамы тұрғысынан сегментациясын көрсетті. Елдегі барлық өңірлерді телевизиялық байланысқа қолжетімАік деңгейі бойынша екіге бөлуге болады: ауы^дық мекендерде телевизиялық байланыстың басым байқалатын тобы және урбанизация деңгейі жоғары топ. Талдау нәтижелері көрсеткендей, цифрлық телевизия барлық, облыстарға енгізілген, мобильді Интернет сымды Интернетпен бәсекелес дамуда.

Зерттеу жұмысының нәтижелері БАҚ аудиториясын және әлеуметтік журналистика мәселелерін зерттеуде практикалық маңызды. Зерттеу жұмысының нәтижелері көрсеткендей, медиаталғамына, ақпаратқа қолжетімдік және қоғамдық көзқарастарына қатысты бұқаралық ақпарат көздерін пайдалану рейтингісі және сенімділік деңгейі ерекшеленетіні дәлелдеАі.

Нәтижесінде, респонденттер қосымша ақпарат көздерін іздеу мақсатында үш арнаны қолданады: телевизия, бейресми арналар және интернет-қорлары. Әзірге тек телевизияның мүмкіндігі арқылы қолжетімді формалды ақпараттың Аәстүрі сақталуда. Аегенмен бұл қағида^арға жастар тобы батыл өзгеріс енгізуде. Ақпарат қорлары ретінде жаңа бұқаралық ақпарат құралдарына - мессенжерлер, әлеуметтік желілер мен Интернет-сайттарға ерекше көп көңіл бөліне бастады. Зерттеу нәтижелерін медиамаркетинг және цифрлық бизнес бойынша қолданбалы жұмыстарға пайдалануға болады.

Түйін сөздер: «Хабар» арнасы, БАҚ аудиториясы, ақпарат көздері, медиатұтыну, медиаталғам, әлеуметтік зерттеулер, әлеуметтік желілер.

\author{
Г.С. Султанбаева ${ }^{1}$ Р. Кертаев ${ }^{2}$, О.П. Аожникова ${ }^{1}$, А. Ашимова ${ }^{1}$ \\ 'Казахский национальный университет им. аль-Фараби, Казахстан, г. А^маты, \\ e-mail: sultanbaeva@gmail.com, \\ e-mail: ol_loj@mail.ru, \\ e-mail: aika910526@hotmail.com \\ 2Евразийский национальный университет им. А.Н. Гумилева, Казахстан, г. Нур-Султан,
} e-mail: rinakhabar@mail.ru

\title{
Цифровые медиапредпочтения в фокусе социальных исследований
}

В статье представлены результаты социлогического исследования по медиаповедению взрослого населения Казахстана, а именно зрителей телеканала «Хабар» в контексте вопроса мировоззренческих ориентаций в цифровую эпоху. Целью исследования является определение специфики медиапотребления цифровых технологий населением Казахстана, в том числе выявления медиапредпочтений современного взрослого населения.

Основными задачами эмпирических исследований являются: определение механизмов доступа к основным техническим средствам коммуникаций и цифровым каналам информации, определение медиаповедения активных пользователей цифровых источников.

Выявление медиаповедения взрослого населения Казахстана, телезрителей канала «Хабар» в фокусе развития и модернизации цифровой эпохы определяет практическую и научную значимость Аанного эмпирического исследования.

Методология исследования основана на количественных и качественных методах: опрос середи целевой группы и работа в фокус-группах. Результаты исследования показывают сегментацию казахстанской аудитории с точки зрения использования цифровых каналов, с точки зрения потребления информации и с точки зрения медиапредпочтений. Все регионы страны можно разделить на Аве группы в соответствии с Аоминирующим типом телевизионной связи: на районы, где преобладает сельское население, и районы с более высоким уровнем урбанизации. Анализ показывает, что цифровое телевидение внедряется во всех областях, и мобильный Интернет начал конкурировать с проводным Интернетом.

Результаты исследования показывают, что сегментация казахстанской аудитории цифровых каналов информации по стилю потребления и особенности медиапредпочтений аудитории телеканала «Хабар» имеют определенные различия. 


\begin{abstract}
Можно сделать вывод, что респонденты в поисках Аополнительной информации пользуются тремя каналами: телевидением, неформальными каналами и интернет-ресурсами. Пока сохраняется традиция формализованного пассивного восприятия информации, которую кучше всего подлерживает телевидение. Но эта традиция уже начинает ломаться на молодежных группах, которые большое внимание как источникам информации уделяют новым СМИ мессенджерам, социальным сетям и интернет-сайтам.

Результаты исследования можно применить в прикладных работах по социальной журналистике, медиамаркетингу и цифровому бизнесу.

Кмючевые слова: телеканал «Хабар», цифровые медиа, цифровая трансформация, медиактивность, медиаповедение, медиапотребление.
\end{abstract}

\section{Introduction}

The digital transformation with its low entry threshold has created unique challenges and opportunities for the market, increasing competition between enterprises, especially in the field of media and communications. The determining factor in digital transformation is its pace of development. Correlation of the speed of technology development and, as a result, digital transformations allows us to state a qualitative jump in the speed of development in the new digital era.

This large-scale task required digital channels for the delivery of information flows that did not exist before. It also needed novel ways of organizing information exchange, which entailed the birth of new media. Along with well-known mediums traditional media, new ones appeared: mobile communications, the Internet, digital television, video games, podcasts, etc. All of them carry within themselves the communicative and social changes that affect every social group.

The digital transformation on the media market intensified competition between TV channels and telecommunications and set new challenges. The level of digital transformation and the pace of development depend on the speed of technology. Of these large-scale tasks, priorities were assigned to the digital channels of the information flow. The methods of organizing the exchange of information have given a bold advantage to the entry of new media into the market. Kazakhstan is recognized as a country that has adopted digital change. The state program «Digital Kazakhstan» has contributed to the widespread use of media and economics, information and communication technologies (https://digitalkz.kz/wpcontent/uploads/2018). The research methodology is based on quantitative and qualitative methods. The results of the study show a segmentation of the Kazakh audience in terms of usage of digital channels, in terms of information consumption and in terms of media preferences. All regions of the country can be divided into two groups according to the dominant type of television connection into areas where rural population prevails and into areas with a higher level of urbanization. The analysis shows that digital television is being introduced in all areas, with mobile Internet having begun to compete with wired Internet.

As of January 15, 2019, 3328 media were registered in Kazakhstan. 2790 of them are the press, 128 are television channels, 70 are radio, and 340 are news agencies and online publications. The traditional press by market share: 2790 newspapers, 990 magazines $(83.8 \%)$. The media register has registered 225 foreign television and radio stations (https://www.cia.gov/library, 2019)

Accelerating the digital transformation of television channels in Kazakhstan is an urgent problem. This is the main development path of the world's leading media tycoons. The digital society has entered the fourth industrial revolution. In 2017, the fact that $50 \%$ of the world's population is fully connected to the high-speed Internet set a clear development threshold (https://kapital.kz, 2019). According to a study conducted by the McKinsey Global Institute (MGI), high-performance media companies switched to using the potential of artificial intelligence (https://www.mckinsey.com ,2019). Many media companies in Kazakhstan have boldly embarked on a digital transformation process. As a result of the implementation of the Digital Kazakhstan program, it gave an impetus to a significant increase in the country's rating.

The information technology change has affected all areas of public life. In the information society, strong media environments began to form, local groups that form the flows of information flows. This stratification is especially noticeable in a social environment with an increased taste of various types of media. The impact of digital media transformation on people's daily lives has increased.

Beneficiaries of the Sandyk Bulak and Sandyk Kenish programs are familiar to all Kazakhstanis. Therefore, the study of media tastes and media activity of the population is in the focus of attention of 
the first large modern media industry of Kazakhstan - Khabar agency is relevant.

The purpose of the study: to determine the media consumption and media tastes of TV channels of the Khabar agency of the population of Kazakhstan.

The objectives of the study: to determine the technical accessibility of Khabar television channel and the activity of viewers, the style of media consumption and the tastes of the media.

Object of study: citizens of the Republic of Kazakhstan over 18 years old.

The research methodology is based on quantitative and qualitative methods: focus group research and questioning among target groups. A sample quota of 2234 respondents made it possible to determine the chosen research goals in terms of demographic parameters, such as age, gender, educational level, social and professional status, and address zone.

\section{Literature review}

Foreign David H. Weaver, Maxwell E. McCombs classic works are devoted to social methods of journalism. Scientists note that social journalism is developing in the framework of the humanistic philosophy of journalism (David H., Willnat W., Willnat L.). The development of digital technology and digital communications has taken this multidisciplinary approach to a new level - the synthesis of social journalism and the digital media industry (Meulemann, H. ,2012).

Many fundamental works on digital media and communications have presented issues of digital transformation based on new thinking and a new model of media development (Litschka, M. (2019), (Cano, C. R., Boles, J. S., \& Bean, C. J. ,2005). Rogers David proposed a media business model and, in his opinion, digital media are more competitive than traditional ones, not to destroy traditional media, but to improve them (Rogers D., 2013). Peter Weil and Stephanie Warner, scientists from the School of Management at the Massachusetts Institute of Technology's Information Technology Center, concluded that digitalization forms an ecosystem of media consumers (Weil P., Warner St.,2019).Information on the digital measurement of consumers is noted in the works of Russian scientists Alexander Prokhorov and Leonid Konik (Prokhorov A., Konik L.,2019) . This is mentioned in the studies of F. Sparacio on artificial intelligence and media architecture (Sparacino F.,2005) In this context, we can mention the research of Schroeder on the medial landscape. The authors analyze the social consequences of digital learning and perception (Schroeder, R. ,2018), (Bilton, C. ,2019).

The classic works of Maxwell J.A. (Maxwell J.A. ,2008)., McCombs (McCombs, M. ,1976) ex- amined the use of social science methods by journalists. Researchers undermine that this method is developing within the framework of the dominant humanistic philosophy of professional journalism.

But with the advent of digital technology and the development of digital communication, this multidisciplinary method has moved to a new level of development of science between social journalism and digital business.

Many publications, which present the issues of digital transformation, are based on the development of new technologies that focus on new business models. Particularly the study by Bilton (Bilton C. 2019) offers a methodology for creating digital business models is given, which has been tested by hundreds of executives around the world. Based on case studies of "digital" companies, the author shows: digital business models not only pose no harm to traditional businesses but, on the contrary, present them a new competitive edge Gambino F. (Gambino F.,2020)

Among the fundamental works of Kazakhstani scientists, we can also note Barmankulov's work "Horizons of Space Television". Thirty years ago, the scientist's hypothesis that television is developing along with online journalism became a reality in the media. Barmankulov anticipated the media preferences of today's audience (Barmankulov M.K. ,1983).

\section{Discussion of the research results:}

Segmentation of Kazakhstan TV channels, in particular, channels of the Khabar agency and features of the consumer style and taste. All regions of Kazakhstan are divided in two types depending on the availability of television channels: the first group is the population with access to television in rural areas; the second - regions and cities with a high level of urban development. The weekly activity of the viewers was the same. The proportion of news sent by the agency through 4 channels is high. The agency accounts for one fifth of the total news coverage of domestic channels. And the most part of the audience watch the programs (own products) of the Khabar channel. The survey shows that viewers prefer informational and sports content. Depending on the share of media consumption, viewers watch the outsourced programs of the Khabar channel.

The general overview of the research audience in Kazakhstan is described in Figure 1. Age characteristics of citizens who took part in a social survey, which included 2234 respondents: $18-24-13 \%, 25-$ $34-46.4 \%, 35-44-23 \%, 45-54-10.4 \%$, 55+ higher $-7.2 \%$. The share of urban population was $54.5 \%$, and rural residents $-45.5 \%$. Frequency of television 
watching: daily $-54.2 \%$, more often than once a week $-24.7 \%$, once a week $-21.2 \%$. In other words, the weekly frequency of watching television is equal. From the point of view of social demography, the population aged 34-24 has an active media audience. One of the goals of the study was to determine the popular- ity of news on the channels. As shown in Figure 2, the utilization rates for all news content targeted at four channels are as follows. This covered $75 \%$ of respondents. It covers one fifth of the total news of domestic channels per agency share (Khabar, Khabar 24, Kazakh TV).

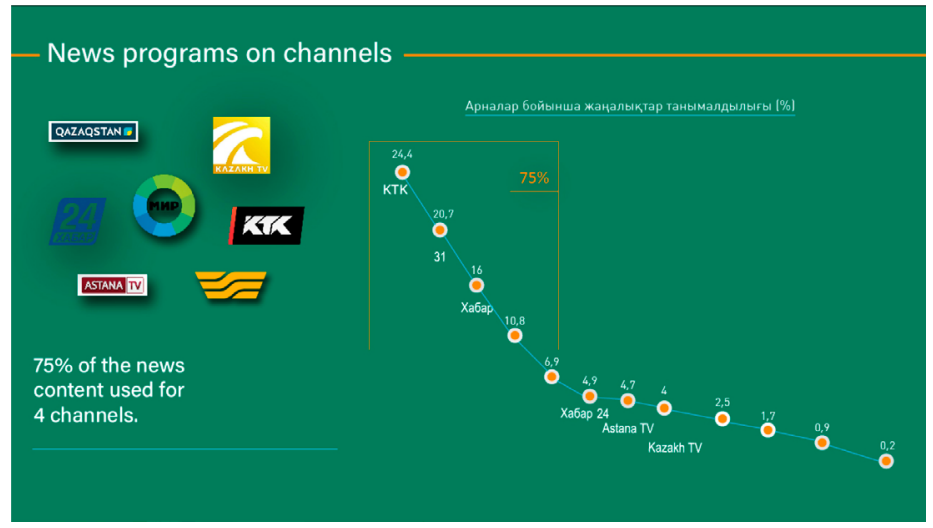

Figure 1 - News programs on the channels

And in terms of scale, it covered 3/4 news coverage in all regions of the country (Figure 2). The share of news news on the channels is as follows:
KTK - 24.4\%; PKE - 20.7\%; Channel 31 - 16\%; Khabar - 10.8\%; Qazaqstan - 6.9\%; Khabar 24 4.9\%; Astana TV - 4.7\%; Kazakh TV - 4\%.

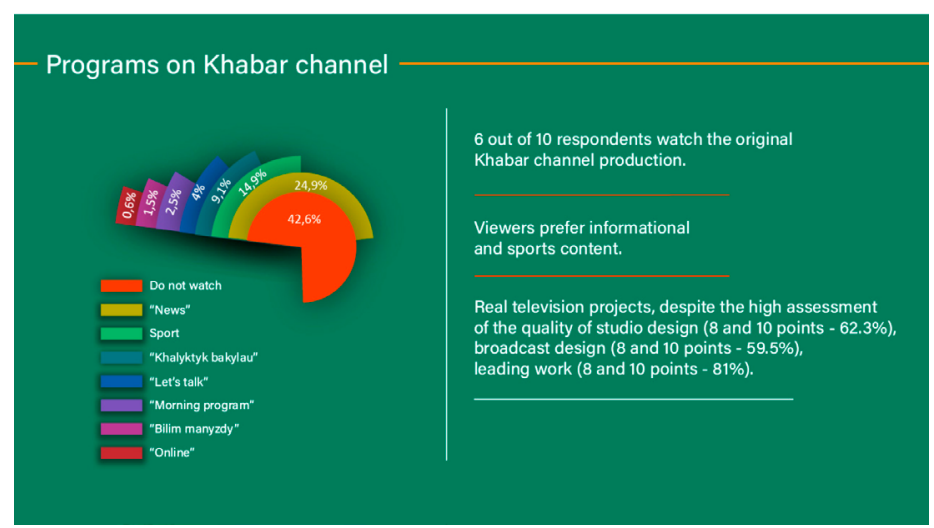

Figure 2 - Programs on the Khabar TV channel

The focus of social research was to determine media consumption and media tastes among viewers about news on the Khabar TV channel (Figure 3 ). The following picture can be analyzed from the audience of the Khabar TV channel: "Kormeimin" $-42.6 \%$; News - 24.9\%; Sports - 14.9\%; "National control" $-9.1 \%$; "Let's talk" - 4\%; "Morning News" $-2.5 \%$; "Vazhno znat" $-1.5 \%$; "Online" $-0.6 \%$.
According to the results of the survey, 6 out of 10 respondents watch their own programs on the Khabar channel. Viewers prefer informational and sports content. Despite the high quality rating of studio design ( 8 and 10 points $-62.3 \%$ ), broadcast design ( 8 and 10 points $-59.5 \%$ ), the work of the presenter ( 8 and 10 points $-81 \%$ ) by the channel's viewers, the demand is relatively small. 


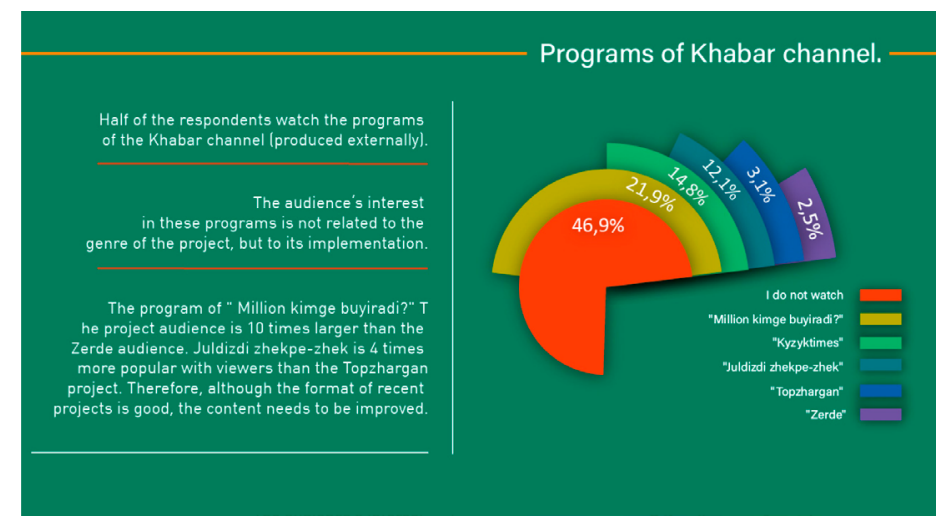

Figure 3 - Programs on the Khabar TV channel

As for the tastes of the audience, the results of the following studies show that the interest of the audience in these programs does not depend on the genre of the project, but on its implementation (Figure 3). "Million kimge buyiradi?" The project audience $(21.9 \%)$ is 10 times higher than the "Zerde" audience (2.5\%). The audience of "Juldizdi jekpe-jek" (12.1\%) is 4 times more popular than the "Topzhargan" project $(3.1 \%)$. Therefore, although the format of recent projects is good, the content needs to be improved.

Depending on the structure of television viewing of the population, the audience of several projects was determined in the next direction of the study (Figure 4).

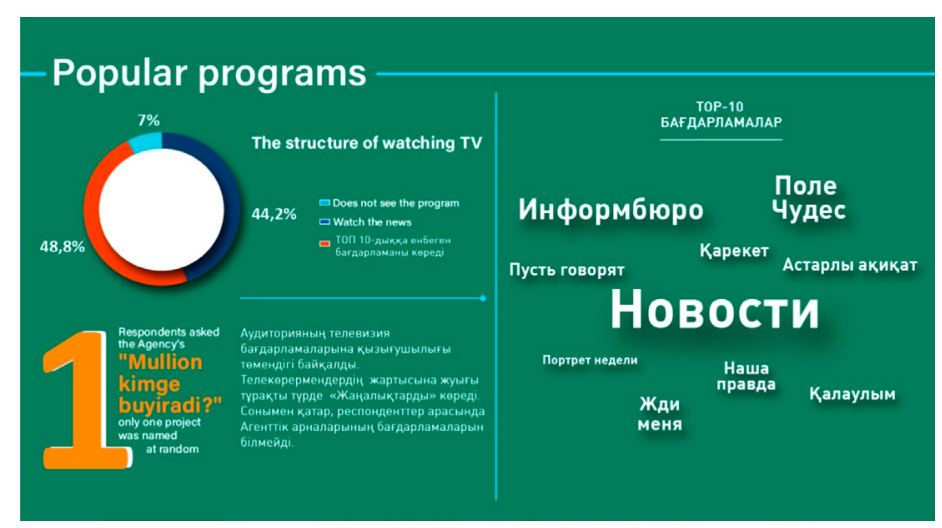

Figure 4 - Popular programs

Respondents noted «Million kimge buyiradi?» project, the share of viewing of the program is high. The proportion of those who do not watch television at all is $7 \%$; follow the news $-44.2 \%$; the preferred program is not included in the TOP $10-48.8 \%$. In addition, respondents are not aware of some of the agency's channel programs. The number of television projects is small due to the impact on their popularity and memory among viewers. The channel is known for broadcasting objective news to the viewers.

Figure 5 shows the level of confidence in television news among people over 18 in the country.
The share of TOP channels in terms of confidence from bottom to top: CPC $-0.4 \%$; Eurasia $-0.5 \%$; Channel 31 - 3.4\%; Khabar - 3.4\%; Qazaqstan - 6.7\%; Khabar 24 - 7.3\%; Astana TV - 8.7\%; Mir - 14.5\%; ABC TV - 17.7\%; KAZAKH TV $-29.5 \%$.

Also, the level of public confidence in the news in the country: watches and trusts $-92.3 \%$; does not watch $-2.9 \%$; does not trust $-3.8 \%$. The highest priority is given to the share of respondents' confidence in the news, including the share of news on the Kazakh TV channel. 
Digital Media Preferences: in the Focus of Social Research

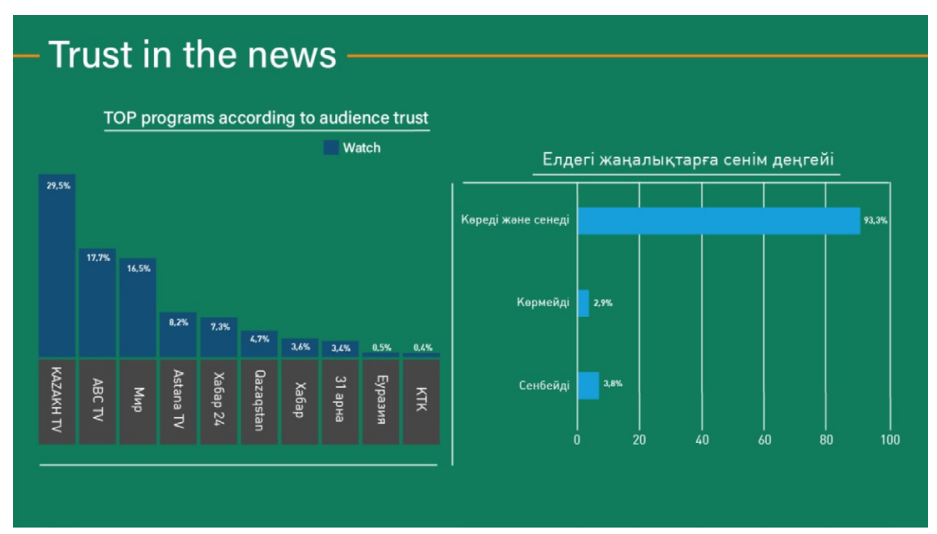

Figure 5 - Trust in the news

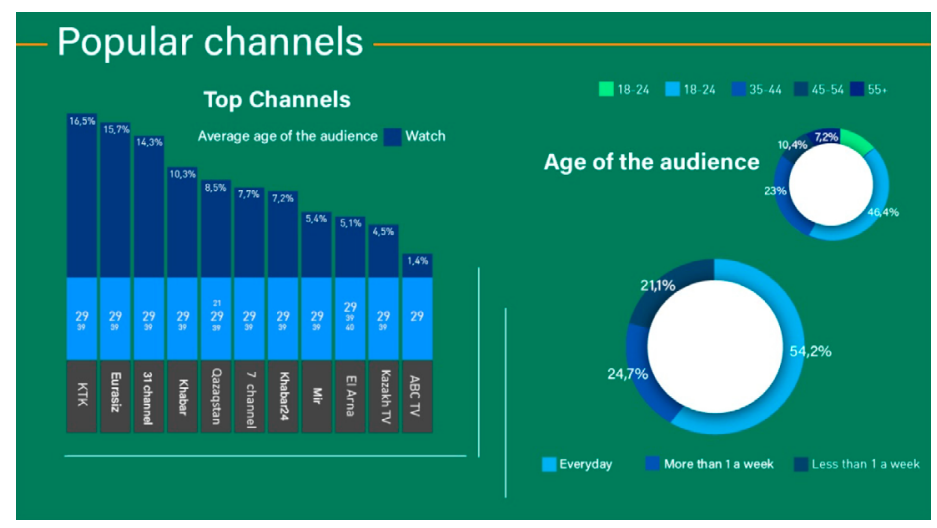

Figure 6 - Popular television channels

The share and importance of fast and highquality television channels in the Kazakhstan media market is significant. Visual and multimedia technologies make the creation of products that meet the tastes of the domestic television audience possible.
Among the best domestic channels are the age characteristics of viewers and the average age of viewers: $18-24 \%$; $25-34-46.4 \%$; $35-44-24.7 \%$; $45-54-10.4 \% ; 50+-7.2 \%$. The results of the study show that young people aged 25-34 are the most active audience (Figure 7).

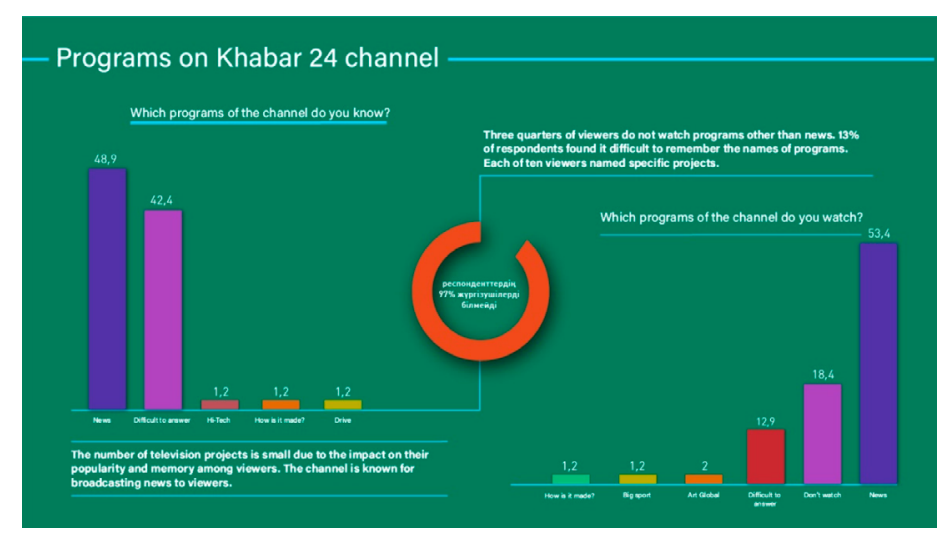

Figure 7 - Programs on the channel Khabar 24 
The popularity of channels is based on the following data: KTK - 16.5\%; Eurasia - 15.7\%; Channel 31 - 14.3\%; Khabar-10.3\%; Qazaqstan-8.5\%; Channel 7 - 7.7\%; Khabar 24 - 7.2\%; Mir - 5.4\%; El Arna $5.1 \%$; KAZAKH TV - 4.5\%; ABC TV - 1.4\%. Most of the target group was named the three leading channels in terms of popularity of Kazakhstan television channels. Khabar channel is in the top three.

Khabar 24 is the only channel in the country that broadcasts news around the clock. Figure 8 shows the results of a survey of viewers and tastes of the media. When asked what programs you know about the channel: News $-48.9 \%$; find difficult to answer $-42.4 \%$; Hi-Tech $-1.2 \%$; How is this made? $1.2 \%$; Drive $-1.2 \%$.
The number of television projects is small due to the impact on their popularity and memory among viewers. The channel is known for broadcasting news to viewers. Three quarters of viewers do not watch programs other than news. $13 \%$ of respondents found it difficult to remember the names of programs. Each of ten channel viewers named specific projects.

When the target audience answered the question, what programs are you watching on the channel, they showed the following results: How is this made? $-1.2 \%$; Big sport - $1.2 \%$; Art Global $-2 \%$; find difficult to answer $-12.9 \%$; do not watch $18.4 \%$; News $-53.4 \%$. More than half of the Khabar 24 viewers are regular viewers of the News Service.

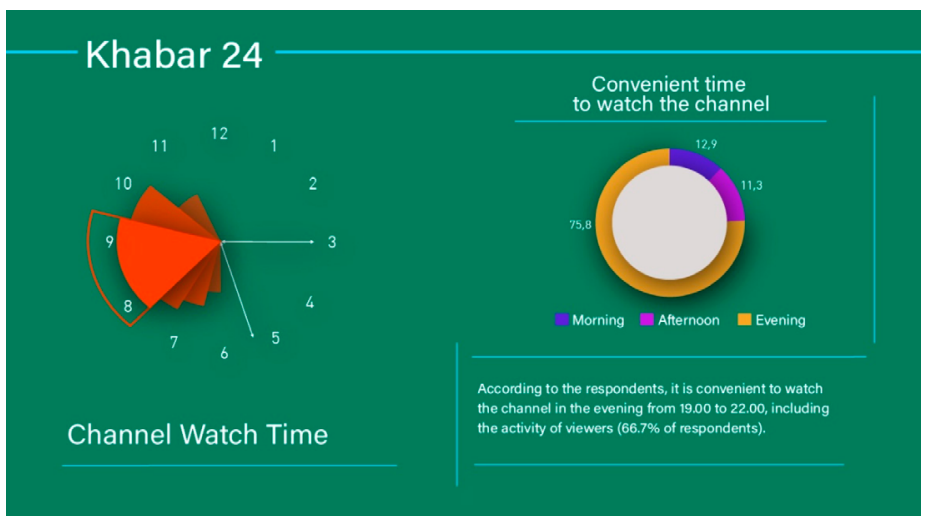

Figure 8 - Khabar 24

Figure 8 shows the media activity of respondents who chose the visual activity of the Khabar-24 channel, and the best time to watch the channel. The share of visual acuity of the audience is as follows: in the morning $-12.9 \%$; during the day $-11.3 \%$; in the evening $-75.8 \%$. According to respondents, it's convenient to watch the channel in the evening from 19.00 to 22.00 , including by the activity of the audience $(66.7 \%$ of respondents).

Theresults of the study show that the segmentation of the Kazakhstani audience of digital channels of information differs by the style of consumption and media preferences. The first group included areas in which the rural population predominates; the second group includes areas with a higher level of urbanization. The analysis of connection types showed that digital television is entering all regions. Mobile Internet has begun to compete with the wired Internet. It can be concluded that three-quarters of all respondents will use three channels in search of additional information: television, informal channels, and Internet resources. For the time being, the tradition of formalized passive perception such as television remains. However, this practice is already starting to break down among the younger population, which pays great attention to new media sources of information such as messengers, social networks and Internet sites. The results of the study can be useful in applied research in media marketing and digital business.

Analysis of the results of the study shows the rating of various sources of information on use and trust in the information disseminated by these sources. It also illustrates the segmentation of the Kazakhstani audience of different channels of information on the style of consumption, features of media preferences depending on various characteristics of respondents, including language preferences. This analysis identifies the characteristics of active and passive audiences of television channels and determines the specifics of media consumption of television media and online media. 


\section{Conclusion}

The result of a sociological study determined the rating and level of reliability of the use of media resources in relation to media tastes, access to information and public relations of the Khabar.

The study identified the segmentation of Kazakhstani television channels, in particular the channels of the Khabar Agency, and revealed the characteristics of the consumer style and tastes of viewers. All regions of Kazakhstan are divided into two depending on the availability of television channels: the first group is the population with access to television in rural areas; the second - regions and cities with a high level of urban development. The weekly activity of viewers and time (evening time $66.7 \%$ ) were clarified.

The level of media connectivity including access to the Internet in rural areas is lower than in urban areas. One of the reasons is the lower level of technical equipment possession among the population in rural areas. It can be noted that the level of access to the mobile Internet in rural areas is higher than to wired Internet. Mobile Internet prevails over wired in Almaty, Kyzylorda, Atyrau, West Kazakhstan, and South Kazakhstan regions. The division of the country's regions by type of television connection is distinguished. In the group with satellite connection ( 8 regions), there were areas in which the rural population prevails, while in the group with cable connection (6 regions and 2 cities), there were areas with a higher level of urbanization.

Of interest is an analysis of the prevalence of types of television services and Internet connections in different regions of Kazakhstan. According to the results of the study, all regions of the country can be divided into two groups according to the dominant type of television connections.

It was proved that the agency has a high share of news aimed at 4 channels and the use of visual, multimedia content. The agency accounts for one fifth of the total news coverage of domestic channels. It turned out that the media preferences of the population pay special attention to the channel's own products. Khabar channel observed an increase in the audience of viewers of its products. The preference of the audience for information and sports content has opened a new direction in the short-term channel strategy. The results of the study proved that the Khabar Agency in the country is a leading media company for the production and distribution of operational, highquality and objective content.

\section{References}

Barmankulov M.K. Vozmozhnosti kosmicheskogo televideniya. - Almaty: Posobie. -1993.19 s.

Bilton, C. (2019). The Disappearing Product and the New Intermediaries. In M. Deuze \& M. Prenger (Eds.), Making Media: Production, Practices, and Professions (pp. 99-110). Amsterdam: Amsterdam University Press. doi: 10.2307/j.ctvcj305r

Cano, C. R., Boles, J. S., \& Bean, C. J. (2005). Communication Media Preferences in Business-to-Business Transactions: An Examination of the Purchase Process. The Journal of Personal Selling and Sales Management, 25(3), 283-294.

David H., Willnat W., Willnat L. Changes in U.S. Journalism: How do journalists think about social media? Journalism Practice, 2016: 1-13

Gambino F. The New Digital Grammar in the Culture of Institutions // Studies in Logic, Grammar and Rhetoric, Volume 59, Issue 1, 2020. - P.27-45.

Litschka, Michael. The Political Economy of Media Capabilities: The Capability Approach in Media Policy// Journal of Information Policy, vol. 9, 2019, pp. 63-94.

Maxwell J.A. (2008). The value of a realist understanding of causality for qualitative research. In N. Denzin (Ed.), Qualitative research and the politics of evidence (pp.163-181). Walnur Creek, CA: Left Coast Press.

McCombs, M. (1976) Handbook of Reporting Methods. Boston: Houghton Mifflin.

Meulemann, H. (2012). Information and Entertainment in European Mass Media Systems: Preferences for and Uses of Television and Newspapers. European Sociological Review, 28(2), 186-202.

Prokhorov A., Konik L. Cifrovaya transformaciya. Analiz, trendy, mirovoj opyt. Digital transformation. Analysis, trends, world experience. 2019

Rogers D. Optimal Clustering of time periods for Electricity demand-side management. IEEE Transactions on Power systems. DOI: 10.1109/TPWRS.2013.2252373

Schroeder, R. (2018). Media systems, digital media and politics. In Social Theory after the Internet: Media, Technology, and Globalization (pp. 28-59). London: UCL Press. doi: 10.2307/j.ctt20krxdr.5

Sparacino Flavia. Intelligent Architecture: Embedding Spaces with a mind for augmented interaction // Human-Computer Interaction - INTERACT 2005: IFIP TC 13, LNCS 3585. - P. 2-3.

Weil Peter, Warner Stephanie: Cifrovaya transformaciya biznesa. Izmenenie biznes-modeli dlya organizacii novogo pokoleniya. (Digital business transformation. Changing the business model for a new generation) - Al'pina Pablisher, $2019-219$ s. 
Digital Implementation Index

State Program "Digital Kazakhstan” https://digitalkz.kz/wp-content/uploads/2018/04/Digital-Kaz_ru.pdf https://www.cia.gov/library/publications/the-world-factbook/fields/199.html

https://kapital.kz/business/80976/kak-uskorit-tsifrovuyu-transformatsiyu-biznesa-v-kazakhstane.html

https://www.mckinsey.com/ /media/McKinsey/Business\%20Functions/McKinsey\%20Digital/Our\%20Insights/Digital\%20 identification $\% 20 \mathrm{~A} \% 20 \mathrm{key} \% 20$ to\%20inclusive $\% 20$ growth/MGI-Digital-identification-Report.ashx

https://www.government.kz/en/news/kazahstan-zanimaet-28-mesto-iz-140-stran-mira-v-reytinge-legkosti-vedeniya-biznesadoing-business

http://dx.doi.org/10.1080/ 17512786. 2016.1171162 